\title{
Calibration and Validation of the AquaCrop Model to Estimate Maize Production in Campos Gerais, Paraná State, Brazil
}

\author{
Jorge Luiz Moretti de Souza ${ }^{1}$ (D), Cibelle Tamiris de Oliveira ${ }^{1}$ (D), Stefanie Lais Kreutz Rosa ${ }^{1}$ (D), \\ Rodrigo Yoiti Tsukahara ${ }^{2}$ \\ ${ }^{1}$ Universidade Federal do Paraná, Departamento de Solos e Engenharia Agrícola, Curitiba, PR, \\ Brazil. \\ ${ }^{2}$ Fundação ABC Pesquisa e Desenvolvimento Agropecuário, Castro, PR, Brazil.
}

Received: 7 March 2019 - Accepted: 12 January 2020

\begin{abstract}
Crop productivity evaluation with models simulations can help in the prediction of harvests and in the understanding of the interactions resulting from the soil-plant-atmosphere continuum. The aim of this study was to calibrate and validate the AquaCrop model for maize crop in the edaphoclimatic conditions of Campos Gerais region, Paraná State, Brazil. The analyses were carried out for maize crop with model input data (climate, crop, soil and soil management) obtained from the ABC Foundation Experimental Station in Castro, Ponta Grossa and Socavão. The climate in the region is humid subtropical, with rainfall evenly distributed. The relief varies from flat to gently undulating. The period analyzed in the calibration and validation process comprised 2011 to 2016 and 2012 to 2016 harvests, respectively. The data used in the calibration of AquaCrop was different from those used in the validation process. Observed and simulated yields were evaluated by simple linear regression analyses, absolute and relative errors, correlation coefficient $(r)$, concordance $(d)$ and performance $(c)$ indexes. The calibration of AquaCrop was satisfactory in the locations studied for maize crop, obtaining absolute errors varying from 6 to $121 \mathrm{~kg} \mathrm{ha}^{-1}$. The highest calibration errors occurred in Castro. However, the errors were not enough to reduce the performance in the validation process for this localitie. The model validation resulted in "excellent" performance in all locations evaluated. The AquaCrop can be used to predict the maize yield with acceptable accuracy in the Campos Gerais Region, Paraná State, Brazil.
\end{abstract}

Keywords: agricultural production, crop models, modeling, Zea mays.

\section{Calibração e Validação do Modelo AquaCrop para Estimar a Produtividade de Milho nos Campos Gerais, Estado do Paraná, Brasil}

\begin{abstract}
Resumo
A avaliação da produtividade das culturas com modelos de simulação pode ajudar na previsão de safras e no entendimento das interações resultantes do sistema solo-planta-atmosfera. Teve-se por objetivo no presente estudo calibrar e validar o modelo AquaCrop para a cultura do milho nas condições edafoclimáticas da região de Campos Gerais, Paraná, Brasil. As análises foram realizadas para a cultura do milho com dados de entrada do modelo (clima, cultura, solo e manejo do solo) obtidos na Estação Experimental da Fundação ABC, em Castro, Ponta Grossa e Socavão. O clima na região é subtropical úmido, com chuvas distribuídas uniformemente. $\mathrm{O}$ relevo varia de plano a suavemente ondulado. $\mathrm{O}$ período analisado no processo de calibração e validação compreendeu as safras de 2011 a 2016, e 2012 a 2016, respectivamente. Os dados utilizados na calibração do AquaCrop foram diferentes dos utilizados no processo de validação. Os rendimentos observados e simulados foram analisados em análises de regressão linear simples, erros absolutos e relativos, coeficiente de correlação $(r)$ e índices concordância $(d)$ e desempenho $(c)$. A calibração do AquaCrop foi satisfatória nos locais estudados para a cultura do milho, obtendo erros absolutos variando de 6 a $121 \mathrm{~kg} \mathrm{ha}^{-1}$. Os maiores erros de calibração ocorreram em Castro. Porém, os erros não foram suficientes para reduzir a performance no processo de validação para essa localidade. A validação do modelo resultou em desempenho "excelente" em todas as localidades avaliadas. O AquaCrop pode ser usado para prever a produção de milho com acurácia aceitável na região de Campos Gerais, Paraná, Brasil.
\end{abstract}

Palavras-chave: produção agrícola, modelos de simulação, modelagem, Zea mays. 


\section{Introduction}

The Campos Gerais, Paraná State, is an important agricultural region that presents yields higher than the national grain production average (IBGE, 2017). Mainly for maize crop, the region is a pioneer in the adoption of new technologies that allow increasing yields even more (Schimandeiro et al. 2008, IBGE, 2017).

Crop yield estimation depends on several factors. Surveys have been managed in the Campos Gerais region to understand the influence of environmental variations on crop yields and water relations, as well as to suggest agricultural management alternatives to increase crop production (Araujo et al. 2009, Araujo et al. 2011, Souza et al. 2013, Souza et al. 2014, Pierri et al. 2016).

The use of models that simulate crop growth is an excellent strategy. Technological advances in software allow conducting tests and experiments, availing data already collected, wrapping few people, low cost, speed, creation and guessing of ideal scenarios to assist in decision making for public and private sectors (Jones et al. 2017).

Seeking to simplify productivity simulation, the Food and Agriculture Organization of the United Nations (FAO) developed the AquaCrop, a dynamic crop model that simulates the attainable yield of herbaceous crops as a function of water consumption (Steduto et al. 2012). AquaCrop differs from other crop simulation models by balancing accuracy, simplicity and robustness. AquaCrop is a crop simulation model that requires a relatively small number of parameters and input data, being mostly-intuitive parameters (Foster et al. 2017).

The use of crop growth models under conditions different that where they were developed is limited. Tests and adaptation are necessary, as yield variability depends largely on weather conditions, which can be particularly altered by climate change (Lecerf et al. 2019), different scenarios and genetic characteristics of the crop used (Picheny et al. 2017, Yin et al. 2018). In general, mathematical crop models require careful calibration and validation to assess their robustness in different environments (He et al. 2017).

The contributions of the AquaCrop have already been verified in research on agricultural management for several crops and countries, but studies evaluating the model performance for Brazilian soil and climate conditions are still scarce. Given the above, the objective of the present study was to calibrate and validate the AquaCrop model for maize crop under Campos Gerais edaphoclimatic conditions, Paraná State.

\section{Material and Methods}

The present study was carried out for three locations in the Campos Gerais region, Paraná State, in Castro $\left(24,85^{\circ} \mathrm{S} ; 49,93^{\circ} \mathrm{W} ; 1001 \mathrm{~m}\right)$, Ponta Grossa $\left(25,01^{\circ} \mathrm{S}\right.$; $\left.50,15^{\circ} \mathrm{W} ; 1000 \mathrm{~m}\right)$ and Socavão, Castro district $\left(24,68^{\circ} \mathrm{S}\right.$; $\left.49,75^{\circ} \mathrm{W} ; 1026 \mathrm{~m}\right)$. According to Koppen's climate classification, the region is classified as $\mathrm{Cfb}$ (humid subtropical, oceanic climate without dry season with temperate summer) (Alvares et al. 2013). Rainfall in the localities is evenly distributed, with rainy season concentrated mainly in February and June and dry season in August (Fig. 1). The annual averages of climate variables are show in Table 1 . The relief varies from flat to gently undulating. The management practice in the areas is no-tillage with residual vegetation covered from the previous harvest, with crop rotation in winter (wheat and black oats) and summer (soybean and maize).

The simulations were carried out with AquaCrop, Version 5.0, developed by Food and Agriculture Organization of the United Nations - FAO (FAO, 2016). One particular feature that distinguishes AquaCrop model from other crop models is the use of canopy cover instead of leaf area index (Raes et al. 2018a). The input data inserted in the AquaCrop, required in the calibration and validation process, consist of information by climate, crop, soil attributes and soil management (Raes et al. 2018b). The data required was:

a) Climate: The maximum and minimum daily air temperature $\left({ }^{\circ} \mathrm{C}\right)$, precipitation $\left(P ; \mathrm{mm}\right.$ day $\left.^{-1}\right)$, relative humidity $(U R ; \%)$, and wind speed $\left(u_{2} ; \mathrm{km} \mathrm{h}^{-1}\right)$ were provided from ABC Foundation historical data (January/ 2011 to April/2016), measured at the automatic agrometeorological stations installed in the analyzed locations, from HygroClipS3 temperature and relative humidity sensors model (Rotronic AG, Bassersdorf, Zurich, Switzerland), wind speed and direction model 3002 at $2.0 \mathrm{~m}$ height (Young, Traverse, MI, USA) and tipping bucket rain gauge with $0.245 \mathrm{~mm}$ resolution, Model ECRN-100 (Decagon, Hopkins, MN, USA). The reference evapotranspiration $\left(E T o ; \mathrm{mm} \mathrm{day}^{-1}\right)$ was estimated with the Penman-Monteith method (Allen et al. 1998), from spreadsheet developed for

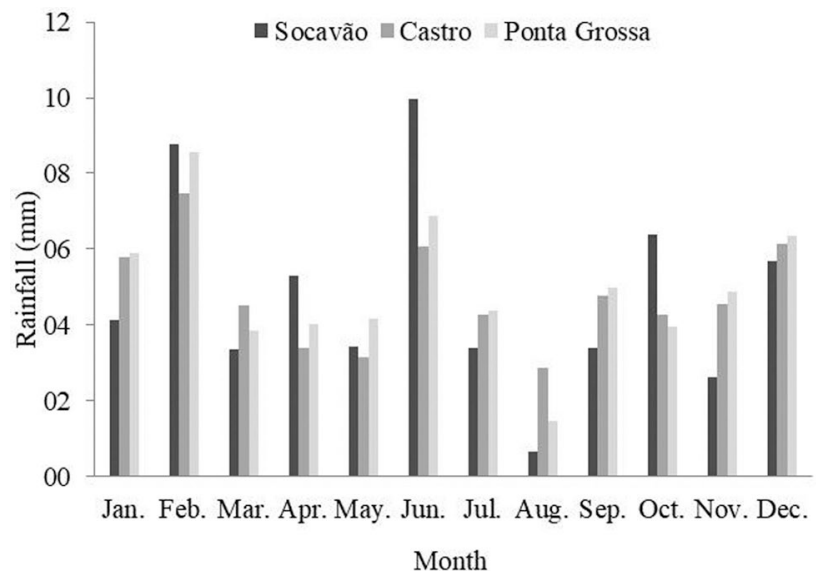

Figure 1 - Average annual pluviometric precipitation in the localities evaluated. 
Table 1 - Annual averages of climate maximum and minimum daily air temperature, precipitation, relative humidity, wind speed and evapotranspiration in the localities evaluated.

\begin{tabular}{|c|c|c|c|c|c|c|c|}
\hline Localitie & Year & $\begin{array}{c}\text { Maximum Temp. } \\
\left({ }^{\circ} \mathrm{C}\right)\end{array}$ & $\begin{array}{c}\text { Minimum Temp. } \\
\left({ }^{\circ} \mathrm{C}\right)\end{array}$ & $\begin{array}{c}\text { Precipitation } \\
(\mathrm{mm})\end{array}$ & $\begin{array}{c}\text { Relative Humidity } \\
(\%)\end{array}$ & $\begin{array}{c}\text { Wind speed } \\
\left(\mathrm{m} \mathrm{s}^{-1}\right)\end{array}$ & $\begin{array}{c}\text { Evapotranspiration } \\
(\mathrm{mm})\end{array}$ \\
\hline \multirow[t]{4}{*}{ Castro } & 2011 & 22.3 & 12.0 & 4.6 & 88.4 & 2.1 & 2.2 \\
\hline & 2012 & 23.5 & 12.7 & 4.4 & 88.2 & 2.1 & 2.3 \\
\hline & 2013 & 23.0 & 12.2 & 4.0 & 86.3 & 2.2 & 2.3 \\
\hline & 2014 & 24.1 & 13.6 & 5.3 & 90.5 & 2.1 & 2.4 \\
\hline \multirow[t]{3}{*}{ Socavão } & 2011 & 23.5 & 11.8 & 16.8 & 3.8 & 84.8 & 2.0 \\
\hline & 2012 & 23.4 & 12.4 & 17.1 & 5.2 & 88.0 & 2.3 \\
\hline & 2013 & 22.3 & 11.9 & 16.4 & 4.5 & 88.2 & 2.7 \\
\hline \multirow{5}{*}{$\begin{array}{l}\text { Ponta } \\
\text { Grossa }\end{array}$} & 2012 & 24.8 & 13.7 & 18.5 & 4.7 & 79.9 & 3.1 \\
\hline & 2013 & 24.1 & 13.0 & 17.8 & 4.7 & 80.5 & 2.9 \\
\hline & 2014 & 25.0 & 14.0 & 18.7 & 4.5 & 80.7 & 2.9 \\
\hline & 2015 & 25.3 & 14.4 & 18.8 & 5.6 & 91.9 & 1.7 \\
\hline & 2016 & 27.9 & 17.2 & 21.5 & 6.2 & 89.5 & 1.6 \\
\hline
\end{tabular}

this purpose. The values of average atmospheric $\mathrm{CO}_{2}$ concentrations (ppm) was provide by the AquaCrop, based on data obtained from the Mauna Loa observatory, Hawaii (Raes et al. 2018b); The climate data inserted in the AquaCrop model to estimate maize production in each localitie are show in Fig. 2.

b) Crop: Sowing and harvest dates, duration of growing cycle (day; emergence, flowering, senescence and maturity) and plant population (plants $\mathrm{ha}^{-1}$ ) was obtained from the $\mathrm{ABC}$ Foundation, from historical data of experiments conducted in experimental stations, in 2011/12 to 2015/16 harvests. The following parameters was calibrated in the model: canopy decline coefficient $(C D C)$; water productivity normalized for ETo e $\mathrm{CO}_{2}\left(W P^{*}\right)$; reference harvest index $\left(H I_{o}\right)$; and crop coefficient $\left(K c_{T r, x}\right)$. The value used for maximum canopy cover was $90 \%$ in all simulations. The other parameters required in the model, such as soil water depletion threshold for canopy expansion, maximum and minimum effective rooting depth, among others, was obtained from Raes et al. (2018d). According to the model options, it was considered that the crop was sensitive to water stress. Salinity was not considered;

c) Soil management: The soil fertility was considered near optimal $(90 \%)$ and since the areas were in no-tillage practice, the soil cover by mulches was fixed in 100\% of unincorporated plant residues. Phytosanitary control and fertilization in the experiments throughout the crop development was performed as required by maize. Irrigation was not considered;

d) Hydraulic properties: Three soil layers $(0-0.10 \mathrm{~m} ; 0.10-$ $0.25 \mathrm{~m}$ and $0.25-0.40 \mathrm{~m}$ depth) were considered for the physical-water attributes. Required data were texture, volumetric water content at permanent wilting point $\left(\theta_{P M P} ; \mathrm{m}^{3} \mathrm{~m}^{-3}\right)$, field capacity $\left(\theta_{C C} ; \mathrm{m}^{3} \mathrm{~m}^{-3}\right)$ and saturation $\left(\theta_{S A T} ; \mathrm{m}^{3} \mathrm{~m}^{-3}\right)$, and saturated hydraulic conductivity $\left(K_{S A T} ; \mathrm{mm}^{-1}{ }^{-1}\right)$ (Table 2$)$.

A total of 26 experiments were used in the AquaCrop calibration process (11 in Castro, 9 in Ponta Grossa and 6 in Socavão) to obtain the simulated yields. In each experiment was entered the conservative and non-conservative parameter values specified for maize, simulated in growing degree-days (GDD) mode, presented in the AquaCrop Reference Manual (Raes et al. 2018d). The growing degree-days mode was chose since crop development is related to temperature. The lower and upper threshold air temperatures values were 10 and $32{ }^{\circ} \mathrm{C}$, respectively. With these values AquaCrop internally converts to GDD mode according to the crop phenological cycle. The parameters were modified and calibrated until the absolute and relative errors of the observed versus simulated yield were minimal, and the " $d$ " index of each experiment were high.

It was used 32 maize experiments for AquaCrop validation process (14 in Castro, 11 in Ponta Grossa and 7 in Socavão), with harvests different from those used in the calibration. It was used the same climate and management data provided by $\mathrm{ABC}$ Foundation, and soil surveyed by Souza et al. (2017) (Table 2). Firstly, the crop data were modified, such as planting date (days), plant population (plants $\mathrm{ha}^{-1}$ ), reference harvest index (\%) and duration of phenological cycle, being this last dependent on plant and cultivation conditions. Afterwards, the calibrated parameters were inserted in the model and the validation process was performed.

In calibration and validation, the simulated yields in AquaCrop $\left(Y_{s}, \mathrm{~kg} \mathrm{ha}^{-1}\right)$ were compared with the observed yields $\left(Y r, \mathrm{~kg} \mathrm{ha}^{-1}\right)$ in simple linear regression analyses. For comparison, it was calculated the mean absolute 

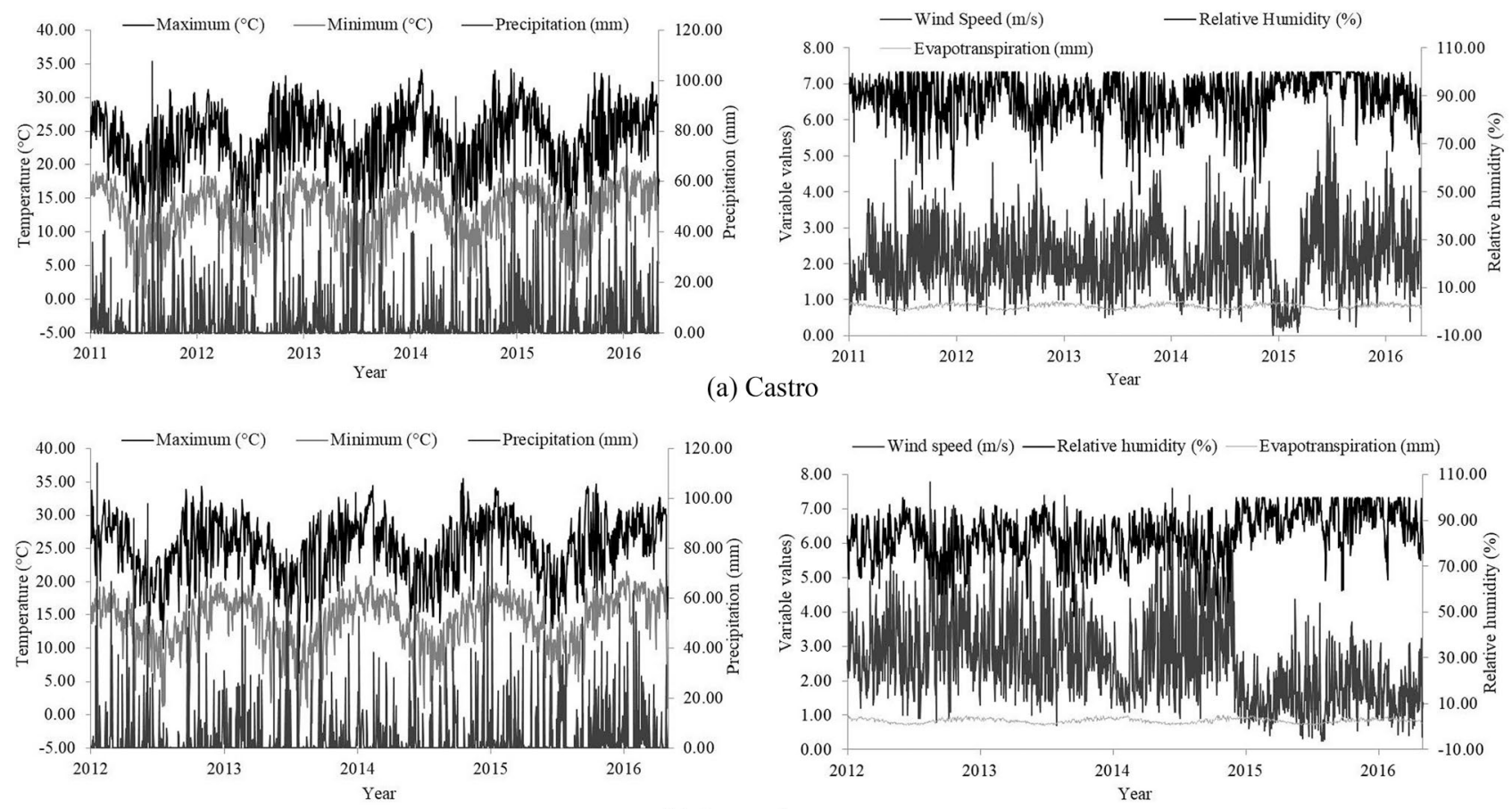

(b) Ponta Grossa
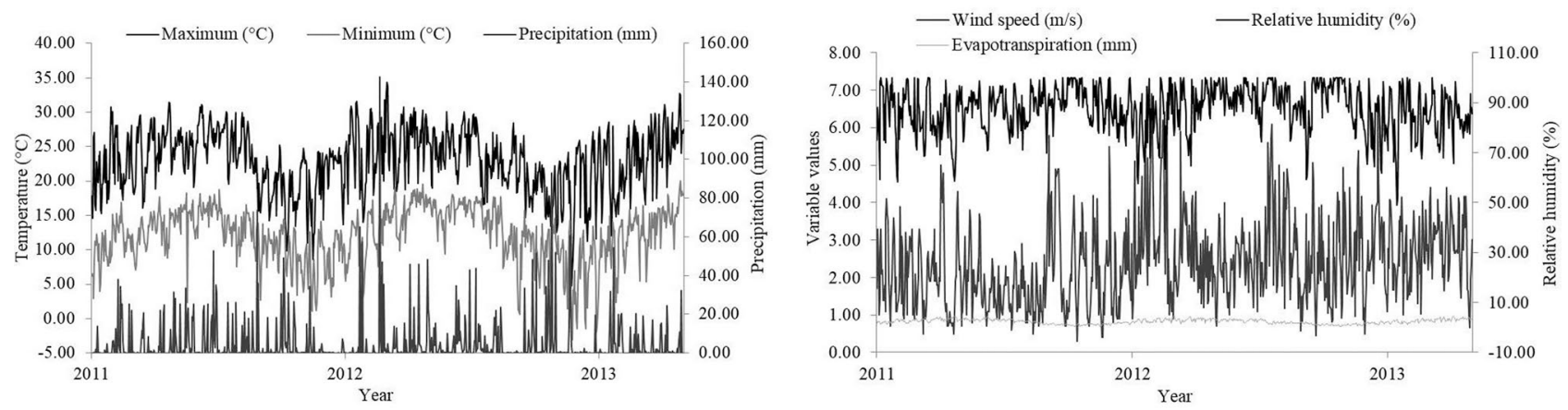

(c) Socavão

Figure 2 - Climate data inserted in the AquaCrop model to estimate maize production in: a) Castro, b) Ponta Grossa, c) Socavão.

Table 2 - Physical-water attributes of the ABC Foundation experimental areas, inserted in AquaCrop, for model parameters calibration and validation.

\begin{tabular}{|c|c|c|c|c|c|c|}
\hline \multirow[t]{2}{*}{ Localitie } & \multirow[t]{2}{*}{ Layer (m) } & \multirow[t]{2}{*}{ Texture } & \multicolumn{3}{|c|}{ Soil water content $\left(\mathrm{m}^{3} \mathrm{~m}^{-3}\right)$} & \multirow[t]{2}{*}{$\mathrm{K}_{\mathrm{sat}}{ }^{(4)}\left(\mathrm{mm}\right.$ day $\left.^{-1}\right)$} \\
\hline & & & $\theta_{\mathrm{PWP}}{ }^{(1)}$ & $\theta_{\mathrm{FC}}{ }^{(2)}$ & $\theta_{\mathrm{Sat}}{ }^{(3)}$ & \\
\hline Castro & $0.00-0.10$ & Clay & 0.36 & 0.50 & 0.63 & 418.32 \\
\hline Castro & $0.10-0.25$ & Clay & 0.33 & 0.47 & 0.60 & 368.23 \\
\hline Castro & $0.25-0.40$ & Clay & 0.32 & 0.45 & 0.62 & 325.74 \\
\hline Ponta Grossa & $0.00-0.10$ & Clay & 0.20 & 0.39 & 0.51 & 743.27 \\
\hline Ponta Grossa & $0.10-0.25$ & Clay & 0.20 & 0.35 & 0.50 & 732.57 \\
\hline Ponta Grossa & $0.25-0.40$ & Clay & 0.25 & 0.36 & 0.54 & 636.30 \\
\hline Socavão & $0.00-0.10$ & Clay & 0.28 & 0.43 & 0.57 & 335.96 \\
\hline Socavão & $0.10-0.25$ & Clay & 0.27 & 0.41 & 0.59 & 351.07 \\
\hline Socavão & $0.25-0.40$ & Clay & 0.24 & 0.40 & 0.59 & 355.54 \\
\hline
\end{tabular}

${ }^{1}$ Volumetric water content at wilting point.

${ }^{2}$ Volumetric water content at field capacity.

${ }^{3}$ Volumetric water content at saturation.

${ }^{4}$ Saturated hydraulic conductivity.

Adapted from Souza et al. (2017). 
$(M A E)$ (Eq. (1)) and relative (MRE) (Eq. (2)) errors, Pearson correlation coefficient $(r)$ (Eq. (3)), " $d$ " (Willmott) (Eq. (4)) and " $c$ " indexes (Camargo \& Sentelhas) (Eq. (5)), which measure model agreement and performance, respectively (Souza, 2018):

$$
\begin{gathered}
M A E=\frac{\sum_{i=1}^{n}\left|Y r_{i}-Y_{S_{i}}\right|}{n} \\
M R E=\frac{\sum_{i=1}^{n}\left|Y r_{i}-Y_{S_{i}}\right|}{\sum_{i=1}^{n} Y_{S_{i}}} \cdot 100 \\
r=\frac{\sum_{i=1}^{n}\left[\left(Y r_{i}-\bar{Y} r\right) \cdot\left(Y_{S_{i}}-\bar{Y}_{S}\right)\right]}{\sqrt{\sum_{i=1}^{n}\left(Y r_{i}-\bar{Y} r\right)^{2} \cdot \sum_{i=1}^{n}\left(Y_{S_{i}}-\overline{Y_{S}}\right)^{2}}} \\
d=1-\frac{\sum_{i=1}^{n}\left(Y_{S_{i}}-Y r_{i}\right)^{2}}{\sum_{i=1}^{n}\left(\left|Y_{S_{i}}-\bar{Y} r\right|+\left|Y r_{i}-\bar{Y} r\right|\right)^{2}} \\
c=d \cdot r
\end{gathered}
$$

where MAE - mean absolute error $\left(\mathrm{kg} \mathrm{ha}^{-1}\right)$; $M R E$ - mean relative error (\%); RMSE - root mean square error $\left(\mathrm{kg} \mathrm{ha}^{-1}\right) ; Y r_{i}-$ real yields observed in the field at each $i$-experiment $\left(\mathrm{kg} \mathrm{ha}^{-1}\right) ; \bar{Y} r$ - real average yields from all cultivars observed in the field $\left(\mathrm{kg} \mathrm{ha}^{-1}\right)$; $Y s_{i}$ - estimated yield observed in the model at each $i$ experiment $\left(\mathrm{kg} \mathrm{ha}^{-1}\right) ; \bar{Y}_{S}-$ observed average yields from all cultivars estimated in the model $\left(\mathrm{kg} \mathrm{ha}^{-1}\right) ; n$ - number of harvests in the localities (unitless); $d-$ " $d$ " index (dimensionless); $r-$ Pearson correlation coefficient (dimensionless); $c-$ " $c$ " index (dimensionless).

The interpretation criteria of " $c$ " performance, was classified by "excellent" ("c" > 0.85 ); "very good" $(0.75<$ "c" $\leq 0.85)$; "good" $(0.65<$ " c" $\leq 0.75)$; "medium" $(0.60<" c " \leq 0.65)$; "tolerable" $(0.50<" c$ " $\leq 0.60)$; "bad" $(0.40<" c " \leq 0.50)$; and, "terrible" ("c" $\leq 0.40)$.

\section{Results and Discussion}

\subsection{Calibration of AquaCrop parameters}

Water intakes in the model were computed by rainfall. During the simulations, both calibration and validation, the soil water content in the model was considered equal to the total available water $(T A W)$, the amount of water a soil can hold between field capacity $(F C)$ and per- manent wilting point $(P W P)$ in the root zone (Raes et al. 2018b).

The calibration analyses were performed using values recommended in the AquaCrop Reference Manual (Raes et al. 2018d). The analyses allowed the most sensitive parameters identification, which deserved more attention in the calibration, as follows: canopy decline coefficient $(C D C)$; crop coefficient when canopy is complete but prior to senescence $\left(K c_{T R, x}\right)$; normalized water productivity for ETo and $\mathrm{CO}_{2}\left(W P^{*}\right)$; and reference harvest index $\left(H I_{o}\right)$.

The sensitivity of $W P^{*}, K c_{T R, x}, C D C$ e $H I_{o}$ parameters is related to be part of two main equations that integrate AquaCrop: dry above-ground biomass ( $B$; Eq. (6)) and grain yield (Y; Eq. (7)).

$$
\begin{gathered}
B=W P \cdot \sum_{i=1}^{n} T r_{i} \\
Y=B . H I
\end{gathered}
$$

where $B-$ dry above-ground biomass $\left(\mathrm{kg} \mathrm{ha}^{-1}\right) ; W P-$ Water productivity parameter $\left(\mathrm{kg} \mathrm{m}^{-2}\right) ; T_{i}-$ crop transpiration at each $i$-period range $(\mathrm{mm}) ; n-$ period considered (unit); $Y$ - crop productivity $\left(\mathrm{kg} \mathrm{ha}^{-1}\right) ; H I-$ crop harvest index (dimensionless) (Raes et al. 2018a).

As part of one of the main equations that compose AquaCrop, the calibration of WP parameter is highly recommended for the environmental conditions under study. $W P^{*}$ is normalized to evapotranspiration (ETo) and atmospheric $\mathrm{CO}_{2}$ concentration. May vary moderately in responses to fertility regime and remain constant under water deficit conditions, except under severe water stresses (Steduto et al. 2012). Raes et al. (2018d) recommend that $W P^{*}=33.7$ must be adopted for maize crop. In the present study the value observed in the calibration process was close (Table 3 ).

The crop transpiration (Tr) depends on the fraction of land area covered by the canopy when there is insufficient stress to limit stomatal opening, being calculated from the ETo and crop transpiration coefficient $\left(K c_{T R, x}\right)$. Thus, indirectly, the $K c_{T R, x}$ parameter is considered in Eq. (6) (Raes et al. 2018c). $K c_{T R, x}$ is proportional to canopy cover $(C C)$ and its value is adjusted over the crop cycle (Raes et al. 2018a). The calibrated $K c_{T R, x}$ value in the present study was the same as suggested by Raes et al. (2018d) for maize crop (Table 3).

The reference harvest index $\left(H I_{o}\right)$ is indicated in the AquaCrop Reference Manual as a conservative parameter for wide crop extension. However, it can be considered cultivar specific (through plant breeding and biotechnology) (Raes et al. 2018d). Thus, it would not be necessary the adjustment of this parameter, and its values (according to the interval recommended in the Manual) could be used for maize crop anywhere in the world. The values indi- 
cated in the Reference Manual were obtained from high yield cultivars, without any restriction in development. However, it is known that some cultivars may have $H I$ consistently either slightly higher or lower than the common cultivars (Steduto et al. 2012), coupled the fact that it is extremely sensitive to changes in the program, which led to the decision of perform the finest adjustment of this parameter in the present study (Table 3). In this study the $H I_{o}$ values were adjusted by using a trial and error approach in order to reduce to the barest minimum the numerical differences between the simulated and measured data.

The canopy decline coefficient $(C D C)$ is a parameter that depends on the cultivar and field conditions in which the plant is inserted. It is used to describe the declining phase due to leaf senescence as the crop approaches maturity. It can also be triggered when water stress becomes severe through early canopy senescence (Raes et al. 2018a). In the present study, the evaluated cultivars presented different times to reach physiological maturity, which justified the limits of values attributed to $C D C$ parameter in calibration process (Table 3). The interval between senescence beginning and physiological maturity was different for cultivars, so the program accounted the influence of $C D C$ on final yield with different intensities.

During the calibration it was observed limiting aspects in the process. It was not possible to calibrate the parameters for the same maize cultivar. The use of different cultivars in the calibration process caused difficulties, such as the different degree-day requirements at each cultivar phenological stage. Each cultivar behaves differently development when inserted in a particular environment. In the literature (Abendipour et al. 2012, Akumaga et al. 2017, Battisti et al. 2017, Ran et al. 2018) there are studies that analyzed much more parameters in the calibration process (duration of phenological stages, canopy growth coefficient, among other parameters considered conservative) than those considered in the present study. The use of more than one cultivar limited the investigation of more parameters at the same time in the calibration process. However, it is believed that they were limitations and not restrictions, considering the edaphoclimatic conditions of the environment studied. Thus, it is noteworthy that the

Table 3 - Final parameters calibrated for maize crop, in Campos Gerais Region, Paraná State.

\begin{tabular}{clc}
\hline Symbol & \multicolumn{1}{c}{ Description } & Values \\
\hline$W P^{*}$ & $\begin{array}{l}\text { Water productivity normalized for } E T o \text { and } \mathrm{CO}_{2} \\
\left(\mathrm{~g} \mathrm{~m}^{-2}\right)\end{array}$ & 32 to 33 \\
$K c_{T R, x}$ & $\begin{array}{l}\text { Crop coefficient when canopy is complete but } \\
\text { prior to senescence }\end{array}$ & 1.05 \\
$C D C$ & Canopy decline coefficient $\left(\% \mathrm{day}^{-1} ; G D D\right)$ & 0.427 to \\
& & 0.489 \\
$H I_{o}$ & Reference harvest index (\%) & 30 to 53 \\
\hline
\end{tabular}

results obtained refer to an appropriate calibration process for maize crop (Table 3) in Campos Gerais Region, Paraná State, since the determination coefficients were satisfactory.

The main aspects observed in the calibrated parameters for maize crop were:

- $W P^{*}$ varied according to the range recommended in the AquaCrop Reference Manual for C4 crops cycle (30 to $35 \mathrm{~g} \mathrm{~m}^{-2}$; Raes et al. 2018a) (Table 3). The values found were close to those indicated by Raes et al. (2018d), which recommend $33.7 \mathrm{~g} \mathrm{~m}^{-2}$ for maize development. As the $W P^{*}$ parameter may vary in response to fertility levels and severe water regime, some authors have observed different values: Abedinpour et al. (2012) obtained $34 \mathrm{~g} \mathrm{~m}^{-2}$ for $W P^{*}$ under different water regimes in India; and Ran et al. (2018) assessing maize under full and deficit irrigation for seed production in China, proposed $W P^{*}=20.9 \mathrm{~g} \mathrm{~m}^{-2}$

- There was no variation in the $K c_{T R, x}$ parameter (Table 3), remaining the same value proposed in the AquaCrop Manual (Raes et al. 2018d). Ngetich et al. (2012) considering three planting dates in two localities, subhumid and semiarid regions of central highlands of Kenya, also used $K c_{T R, x}=1.05$ for maize. Other studies have also obtained simulated yields very similar to those observed in the field by assigning $K c_{T R, x}=$ 1.03 for maize crop; Heng et al. (2009) in the localities of Bushland (Texas), Gainesville, (Florida) and Zaragoza (Spain); Hsiao et al. (2009) under different irrigation levels in California; Abendipour et al. (2012) in India; and Akumaga et al. (2017) under different nitrogen levels in Nigeria.

- The canopy decline coefficient $(C D C$ ) basically depends on the cultivar behavior in the environment. In analyses, the $C D C$ values (Table 3 ) varied when compared to values obtained in the literature. Heng et al. (2009), Hsiao et al. (2009), Abendipour et al. (2012) and Akumaga et al. (2017) found $C D C=1.06 \%$ day $^{-1}$ for maize, in different regions from the one used in the present study;

- The reference harvest index $\left(H I_{o}\right)$ may vary between genotypes, also depending on the environment in which crops are inserted. The $H I_{o}$ values had large variation among the cultivars used (23\%; Table 3$)$, probably due to the differences between genotypes, plant population and variation on climatic conditions. Ngetich et al. (2012) obtained $H I_{o}=48 \%$, as did Hsiao et al. (2009) for the cultivars Dekalb XL22, Dekalb XL25A, Dekalb 535 and Dekalb 591. Akumaga et al. (2017) considered $H I_{o}=40 \%$ and Abendipour et al. (2012) a range of values from 22.3 to $34.4 \%$.

Overall, the absolute and relative errors obtained in the maize crop calibration analyses were small (Table 4). The highest value occurred in Castro $\left(M A E=121 \mathrm{~kg} \mathrm{ha}^{-1}\right.$ 
and $M R E=1.17 \%$; genotype P2530; 2015/2016 harvest) and the lowest in Ponta Grossa $\left(M A E=6 \mathrm{~kg} \mathrm{ha}^{-1}\right.$ and $M R E=0.05 \%$; genotype P30R50H; 2012/2013 harvest).
The mean absolute and relative errors found for Castro $\left(M A E=70.09 \mathrm{~kg} \mathrm{ha}^{-1}\right.$ and $\left.M R E=0.63 \%\right)$, Ponta Grossa $\left(M A E=75.44 \mathrm{~kg} \mathrm{ha}^{-1}\right.$ and $\left.M R E=0.69 \%\right)$ and Socavão

Table 4 - Mean absolute (MAE) and relative (MRE) errors obtained in the calibration and validation between observed $(Y r)$ and simulated $(Y S)$ yields for maize crop, in AquaCrop model, for experiments installed in Castro, Ponta Grossa and Socavão.

\begin{tabular}{|c|c|c|c|c|c|c|c|c|c|c|c|}
\hline \multirow{3}{*}{ Cultivar } & \multicolumn{5}{|c|}{ Calibration } & \multirow{3}{*}{ Cultivar } & \multicolumn{5}{|c|}{ Validation } \\
\hline & \multirow[t]{2}{*}{ Harvest } & \multirow{2}{*}{$\begin{array}{c}Y r \\
\mathrm{~kg} \mathrm{ha}^{-1}\end{array}$} & \multirow{2}{*}{$\begin{array}{l}Y S \\
\%\end{array}$} & \multirow{2}{*}{$\begin{array}{c}|M A E| \\
\mathrm{kg} \mathrm{ha}^{-1}\end{array}$} & \multirow{2}{*}{$\begin{array}{c}\text { MRE } \\
\% \\
\end{array}$} & & \multirow[t]{2}{*}{ Harvest } & \multirow{2}{*}{$\begin{array}{c}Y r \\
\mathrm{~kg} \mathrm{ha}^{-1}\end{array}$} & \multirow{2}{*}{$\begin{array}{c}Y S \\
\mathrm{~kg} \mathrm{ha}^{-1} \\
\end{array}$} & \multirow{2}{*}{$\begin{array}{c}|M A E| \\
\mathrm{kg} \mathrm{ha}^{-1}\end{array}$} & \multirow{2}{*}{$\begin{array}{c}\text { MRE } \\
\% \\
\end{array}$} \\
\hline & & & & & & & & & & & \\
\hline \multicolumn{12}{|l|}{ Castro } \\
\hline P32R22H & $2011 / 12$ & 12453 & 12550 & 97 & 0.77 & 30R50YH & $2014 / 15$ & 14418 & 14530 & 112 & 0.77 \\
\hline P30R50YH & $2013 / 14$ & 13554 & 13440 & 114 & 0.85 & AG8041PRO & $2014 / 15$ & 14293 & 14383 & 90 & 0.63 \\
\hline AG8041PRO & $2013 / 14$ & 13078 & 13088 & 10 & 0.08 & 30F53YH & $2014 / 15$ & 14439 & 14482 & 43 & 0.30 \\
\hline P30F53YH & $2013 / 14$ & 14681 & 14659 & 22 & 0.15 & Velox TL & $2014 / 15$ & 14111 & 14247 & 136 & 0.95 \\
\hline Celeron TL & $2013 / 14$ & 12987 & 12896 & 91 & 0.71 & WXA 504 Waxy & $2014 / 15$ & 12495 & 12474 & 21 & 0.17 \\
\hline DKB240PRO & $2015 / 16$ & 14348 & 14366 & 18 & 0.13 & DKB 240PRO & $2014 / 15$ & 14663 & 14741 & 78 & 0.53 \\
\hline P30R50YH & $2015 / 16$ & 12734 & 12819 & 85 & 0.66 & 30R50YH & $2014 / 15$ & 10940 & 10948 & 8 & 0,07 \\
\hline P1630H & $2015 / 16$ & 9815 & 9859 & 44 & 0.45 & AG8041PRO & $2014 / 15$ & 10902 & 10774 & 128 & 1.19 \\
\hline P2530 & $2015 / 16$ & 10188 & 10309 & 121 & 1.17 & $\mathrm{P} 32 \mathrm{R} 22 \mathrm{H}$ & $2014 / 15$ & 10746 & 10715 & 31 & 0.29 \\
\hline DKB240PRO & $2015 / 16$ & 9497 & 9400 & 97 & 1.03 & $30 \mathrm{~F} 53 \mathrm{YH}$ & $2014 / 15$ & 12340 & 12208 & 132 & 1.08 \\
\hline P30R50YH & $2015 / 16$ & 7758 & 7830 & 72 & 0.92 & Velox TL & $2014 / 15$ & 9962 & 9850 & 112 & 1.14 \\
\hline All harvests & - & 11918 & 11929 & 70.09 & 0.63 & AS 1656PRO2 & $2014 / 15$ & 10884 & 10812 & 72 & 0.67 \\
\hline- & - & - & - & - & - & WXA 504 Waxy & $2014 / 15$ & 10899 & 10768 & 131 & 1.22 \\
\hline- & - & - & - & - & - & DKB 240PRO & $2014 / 15$ & 9309 & 9663 & 354 & 3.66 \\
\hline- & - & - & - & - & - & All harvests & - & 12172 & 12185 & 103.43 & 0.90 \\
\hline \multicolumn{12}{|l|}{ Ponta Grossa } \\
\hline P30R50H & $2012 / 13$ & 12239 & 12233 & 6 & 0.05 & 30R50YH & $2015 / 16$ & 11902 & 11738 & 164 & 1.40 \\
\hline P32R22H & $2013 / 14$ & 10233 & 10117 & 116 & 1.15 & AG8041PRO & $2015 / 16$ & 12681 & 12750 & 69 & 0.54 \\
\hline $\mathrm{P} 32 \mathrm{R} 22 \mathrm{H}$ & $2013 / 14$ & 10262 & 10192 & 70 & 0.69 & $\mathrm{P} 32 \mathrm{R} 22 \mathrm{H}$ & $2015 / 16$ & 10520 & 10517 & 3 & 0.03 \\
\hline P30F53YH & $2014 / 15$ & 11369 & 11336 & 33 & 0.29 & 30F53YH & $2015 / 16$ & 11306 & 11303 & 3 & 0.03 \\
\hline AG8041PRO & $2015 / 16$ & 11099 & 11217 & 118 & 1.05 & Velox TL & $2015 / 16$ & 11663 & 11781 & 118 & 1.00 \\
\hline Velox TL & $2015 / 16$ & 10017 & 10060 & 43 & 0.43 & AS 1656PRO2 & $2015 / 16$ & 13401 & 13470 & 69 & 0.51 \\
\hline AS 1656PRO2 & $2015 / 16$ & 11347 & 11465 & 118 & 1.03 & WXA 504 Waxy & $2015 / 16$ & 11010 & 11073 & 63 & 0.57 \\
\hline WXA 504 Waxy & $2015 / 16$ & 10417 & 10530 & 113 & 1.07 & DKB 240PRO & $2015 / 16$ & 12273 & 12144 & 129 & 1.06 \\
\hline DKB 240PRO & $2015 / 16$ & 12577 & 12639 & 62 & 0.49 & 30R50YH & $2015 / 16$ & 11878 & 11885 & 7 & 0.06 \\
\hline All harvests & - & 11062 & 11088 & 75.44 & 0.69 & P32R22H & $2015 / 16$ & 9352 & 9391 & 39 & 0.42 \\
\hline - & - & - & - & - & - & 30F53YH & $2015 / 16$ & 11383 & 11471 & 88 & 0.77 \\
\hline- & - & - & - & - & - & All harvests & - & 11579 & 11593 & 68.36 & 0.58 \\
\hline \multicolumn{12}{|l|}{ Socavão } \\
\hline P30R50H & $2011 / 12$ & 13513 & 13584 & 71 & 0.52 & P30R50YH & $2012 / 13$ & 10659 & 11837 & 1178 & 9.95 \\
\hline AG8041YG & 2011/12 & 11981 & 11924 & 57 & 0.48 & AG8041PRO & $2012 / 13$ & 13341 & 13395 & 54 & 0.40 \\
\hline P32R22H & $2011 / 12$ & 13713 & 13741 & 28 & 0.20 & P30R50YH & $2013 / 14$ & 13110 & 13239 & 129 & 0.97 \\
\hline P1630H & $2012 / 13$ & 12045 & 12021 & 24 & 0.20 & AG8041PRO & $2013 / 14$ & 13661 & 13686 & 25 & 0.18 \\
\hline $30 \mathrm{~F} 53 \mathrm{YH}$ & $2012 / 13$ & 13155 & 13218 & 63 & 0.48 & $\mathrm{P} 2530 \mathrm{H}$ & $2013 / 14$ & 13674 & 13507 & 167 & 1.24 \\
\hline Celeron TL & $2012 / 13$ & 11606 & 11538 & 68 & 0.59 & $30 \mathrm{~F} 53 \mathrm{YH}$ & $2013 / 14$ & 13970 & 13820 & 150 & 1.09 \\
\hline All harvests & - & 12669 & 12671 & 51.83 & 0.41 & Celeron TL & $2013 / 14$ & 13002 & 13171 & 169 & 1.28 \\
\hline- & - & - & - & - & - & - & - & 13060 & 13236 & 267.43 & 2.16 \\
\hline All localities & - & 11795 & 11809 & 67.73 & 0.60 & - & - & 12162 & 12212 & 127.25 & 1.07 \\
\hline
\end{tabular}


$\left(M A E=51.83 \mathrm{~kg} \mathrm{ha}^{-1}\right.$ and $\left.M R E=0.41 \%\right)$ were small and very close. On average, considering all harvests, small absolute $\left(M A E=67.73 \mathrm{~kg} \mathrm{ha}{ }^{-1}\right)$ and relative $(M R E=0.60 \%)$ errors were obtained, resulting in an excellent calibration for maize crop in Campos Gerais. The average $M A E$ values obtained for maize in Campos Gerais were better than those verified by Abendipour et al. (2012) and Akumaga et al. (2017) for India (170 $\left.\mathrm{kg} \mathrm{ha}^{-1}\right)$ and Nigeria $\left(164 \mathrm{~kg} \mathrm{ha}^{-1}\right.$ ), respectively.

The coefficients of determination and " $d$ " index obtained in Castro, Ponta Grossa and Socavão had excellent results $\left(\mathrm{R}^{2}=1.0 ; d=1.0\right)$, indicating a perfect association between estimated and observed yield values (Fig. 3). The $\mathrm{R}^{2}$ values and " $d$ " index considering yields observed in the field and estimated in the program, for all localities, also showed excellent results in the association and calibration (Fig. 3d). Similar results were verified for by Abendipour et al. (2012) and Akumaga et al. (2017).

\subsection{Validation of AquaCrop parameters}

With the parameters calibrated for maize crop (Table 3), the validation analyses of the AquaCrop model (Table 4) were performed. After adjusting the parameters, it was observed that the calibration provided excellent validation responses, except for the P30R50YH genotype in Socavão city $(M A E=1178 \mathrm{~kg}$ $\mathrm{ha}^{-1} ; M R E=9.95 \mathrm{~kg} \mathrm{ha}^{-1} ; 2012 / 2013$ harvest). The yield observed in this harvest $\left(Y r=10659 \mathrm{~kg} \mathrm{ha}^{-1}\right)$ was $18.38 \%$ below the average of the other harvests used to validate maize $\left(13059.6 \mathrm{~kg} \mathrm{ha}^{-1}\right)$ in Socavão. The main problem may be related to the high water content in the soil before planting. In 17 days preceding the planting of this experiment, precipitation was approximately $265 \mathrm{~mm}$. Piekarski et al. (2017) also verified in analyses for maize crop, in Campos Gerais, that Aquacrop presented high difficult to simulate yields far from the average. Even adopting the calibration parameters that result in lower simulated productivity in AquaCrop, it was note that the productivity observed in the field was even lower. It is believed that in this harvest occurred problems with pests, diseases or weeds, which caused a decrease in productivity. However, in general, the analyses performed in the present study for Castro and Ponta Grossa showed MAE and MRE validation results very similar to those obtained in calibration (Table 4).

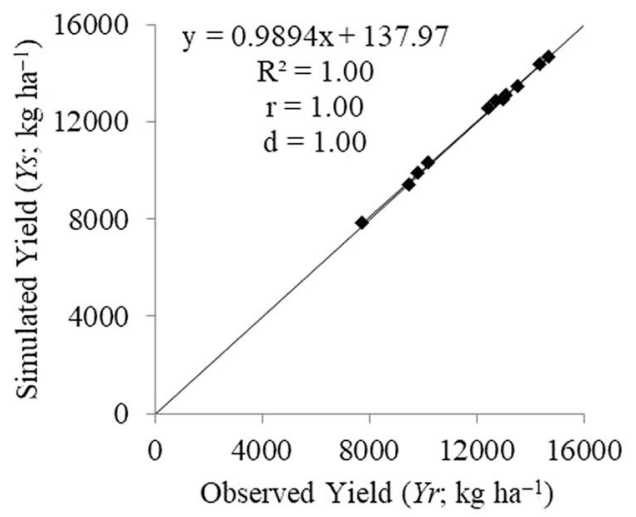

(a) Castro

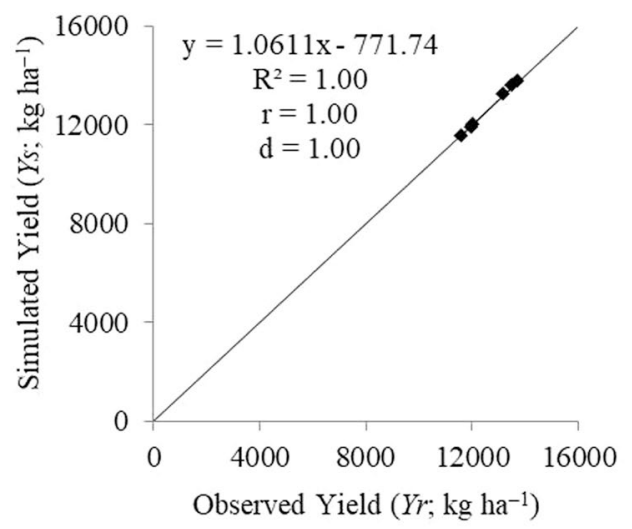

(c) Socavão

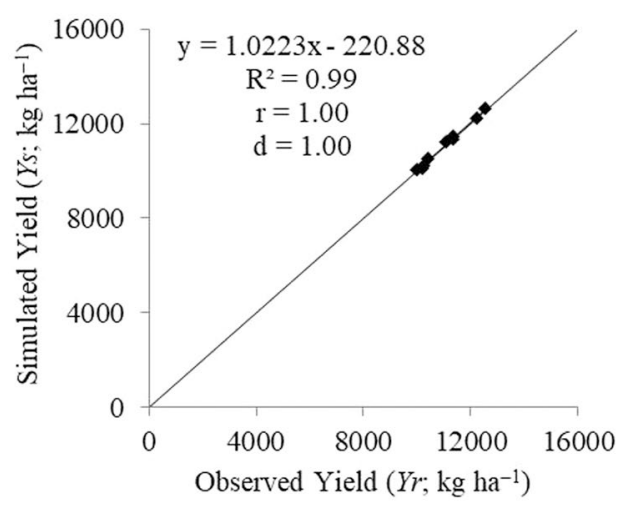

(b) Ponta Grossa

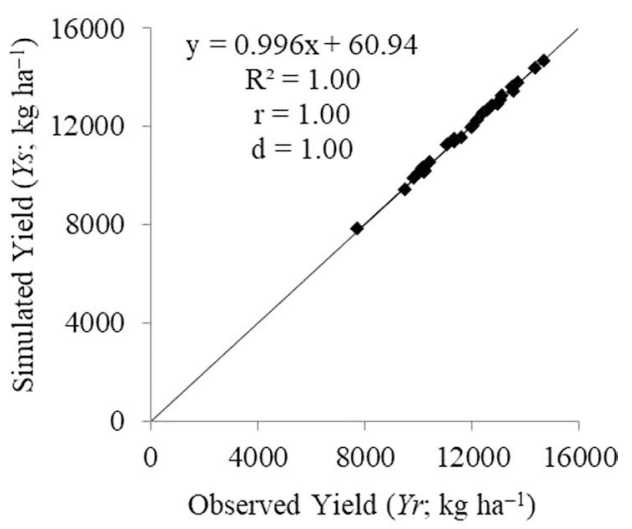

(d) Castro, Ponta Grossa and Socavão together

Figure 3 - Linear regression analyses and respective coefficient of determination $\left(\mathrm{R}^{2}\right)$ and " $d$ " index, obtained in the calibration, between observed and simulated yield for maize crop in the AquaCrop model, in: a) Castro, b) Ponta Grossa, c) Socavão, d) Castro, Ponta Grossa and Socavão together. 


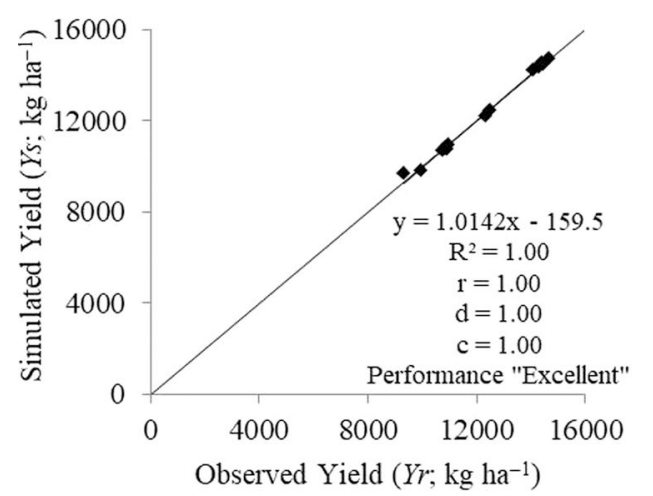

(a) Castro

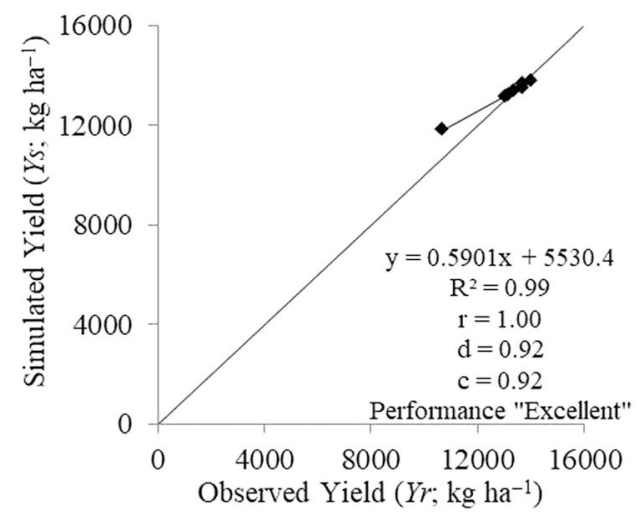

(c) Socavão

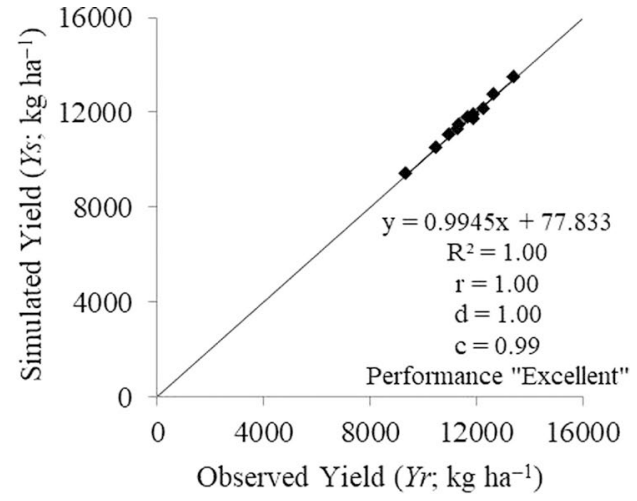

(b) Ponta Grossa

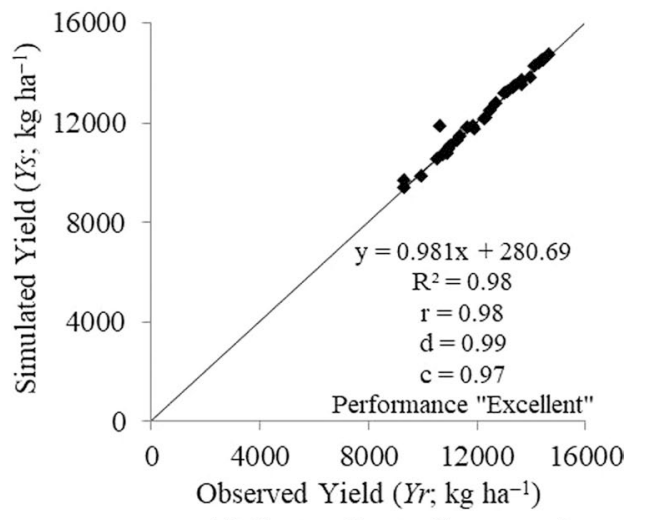

(d) Castro, Ponta Grossa and Socavão together

Figure 4 - Linear regression analyses and respective coefficient of determination $\left(\mathrm{R}^{2}\right)$, " $d$ " and " $c$ " indexes, obtained between observed and simulated maize productivity in the AquaCrop model validation, in: a) Castro; b) Ponta Grossa; c) Socavão; and d) Castro, Ponta Grossa and Socavão together.

The best model performance in Ponta Grossa was due to the better adjustment of the model parameters. Also in this localitie, a higher volume of average precipitation was observed (Table 1), providing more available water for plants, which may have contributed even more to obtain the lowest absolute and relative errors observed in the localitie.

The worst performance observed in Socavão was due to the low number of harvest available for the calibration process. Thus, it was not possible to properly adjust the parameter values, which reflected in larger errors in the validation. Removing 2012/2013 harvest (genotype P30R50YH), Socavão also presented validation results $\left(M A E=115.67 \mathrm{~kg} \mathrm{ha}^{-1}\right.$ and $\left.M R E=0.86 \%\right)$ very close to those verified in calibration $\left(M A E=51.83 \mathrm{~kg} \mathrm{ha}^{-1}\right.$ and $M R E=0.41 \%$ ). On average, considering all harvests and localities analyzed, there was an $M A E=127.25 \mathrm{~kg} \mathrm{ha}^{-1}$ and $M R E=1.07 \%$ between the real and estimated yields (Table 4) in relation to $M R E=0.60 \%$ verified in calibration. In the literature, the average $M A E$ values found were $110 \mathrm{~kg} \mathrm{ha}^{-1}$ for maize in India (Abendipour et al. 2012) and ranging from 108 to $419 \mathrm{~kg} \mathrm{ha}^{-1}$ in Nigeria (Akumaga et al. 2017).
Validation analyses performed in Castro $\left(\mathrm{R}^{2}=1.0\right)$, Ponta Grossa $\left(R^{2}=0.99\right)$ and Socavão $\left(R^{2}=0.99\right)$ cities had a coefficient of determination close to the unit, between observed and simulated productivities (Fig. 4). The results indicate consistency in the calibrated parameters used on validation analyses, resulting in reliable data to simulate maize yield in the region. Regression analyses involving all localities also obtained excellent results $\left(\mathrm{R}^{2}=0.98\right)$.

The " $d$ " indexes obtained in the analyses also had results similar to those verified for coefficients of determination $\left(\mathrm{R}^{2}\right)$, with values very close to the unit (perfect agreement) in all analyses. The results are promising, since the yields (simulated and observed) presented great association and close to the 1:1 line in dispersion diagram (Fig. 4), indicating that the calibration of the AquaCrop model for maize crop was very satisfactory in Campos Gerais edaphoclimatic conditions, State of Paraná, Brazil.

The AquaCrop model obtained "excellent" performance to estimate productivities in Castro $(c=1.0)$, Ponta Grossa $(c=0.99)$ and Socavão $(c=0.92)$. The results of all harvests analyzed together also resulted in "excellent" performance $(r=0.98, d=0.99$ and $c=0.97)$. The " $c$ " 
index is a very strict penalty coefficient in model validation analyses, and even so the results obtained were very favorable. Hsiao et al. (2009) also found good correlation between observed and simulated yields, obtaining $r=0.99$ for maize in California. On the other hand, Akumaga et al. (2017) obtained index of agreement in validation lower than the one found in the present study ( $d$ values ranging from 0.63 to 0.88 ) for maize in Nigeria. Ngetich et al. (2012) also obtained " $d$ " $=0.99$ for two locations evaluated in Kenya.

\section{Conclusions}

The calibration of AquaCrop model to estimate maize productivity in Campos Gerais Region, Paraná State, Brazil, resulted in small absolute errors (6 to $\left.121 \mathrm{~kg} \mathrm{ha}^{-1}\right)$.

The best performance of the AquaCrop model in Ponta Grossa was due to the better adjustment of the model parameters, associated with the higher average precipitation was observed in the localitie.

The worst performance observed in Socavão was due to the low number of harvest available for the calibration process, which reflected in larger errors in the validation.

Good associations between yields observed in the field and simulated in the model, in the validation process, showed that the AquaCrop calibration for maize crop under Campos Gerais edaphoclimatic conditions was very satisfactory, presenting "excellent" performance in yield estimates for all locations evaluated.

The AquaCrop model can be used to predict maize yield with acceptable accuracy in the Campos Gerais Region, Paraná State, Brazil, being an interesting and inexpensive alternative tool in crop decision making for the region, such as irrigation management and different planting dates. The main caution that should be taken when using AquaCrop is to adjust the model parameters for the conditions in which the crop is inserted, since the use of discrepant values may cause under or over yield estimation.

\section{References}

ABENDIPOUR, M.A.; SARANGI, A.; RAJPUT, T.B.S.; PATHAK, H.; AHMAD, T. Performance evaluation of AquaCrop model for maize crop in a semi-arid environment. Agricultural Water Management, v. 110, p. 55-66, 2012.

AKUMAGA, U.; TARHULE, A.; YUSUF, A.A. Validation and testing of the FAO AquaCrop model under different levels of nitrogen fertilizer on rainfed maize in Nigeria, West Africa. Agricultural and Forest Meteorology. v. 232, p. 225-234, 2017.

ALLEN, R.G.; PEREIRA, L.S.; RAES, D.; SMITH, M. Crop evapotranspiration: Guidelines for computing crop water requirements. Irrigation and Drainage Paper $\mathrm{N}^{\circ} 56$, Rome: FAO, 1998.

ALVARES, C.A.; STAPE, J.L.; SENTELHAS, P.C.; GONÇALVES, J.L.M.; SPAROVEK, G. Köppens's climate classification map for Brazil. Meteorologische Zeitschrift, v. 22, n. 6, p. 711-728, 2013.

ARAUJO, M.A.; SOUZA, J.L.M.; BRONDANI, G.E.; PAULETTI, V. Sistemas de manejo e relações hídricas do solo na produtividade da cultura da soja, em Ponta GrossaParaná. Scientia Agraria, Curitiba, v. 10, n. 5, p. 403-412, 2009.

ARAUJO, M.A.; SOUZA, J.L.M.; TSUKAHARA, R.Y. Modelos agrometeorológicos na estimativa da produtividade da cultura da soja na região de Ponta Grossa, Estado do Paraná. Acta Scientiarum. Agronomy, Maringá, v. 33, n. 1, p. 23-31, 2011.

BATTISTI, R.; SENTELHAS, P.C.; BOOTE, K.J. Inter-comparison of performance of soybean crop simulation models and their ensemble in Southern Brazil. Field Crops Research, v. 200, p. 28-37, 2017.

FOOD AND AGRICULTURE ORGANIZATION OF THE UNITED NATIONS. AquaCrop. 2016. Available at: $<$ http://www.fao.org/aquacrop/software/en/>. Access on: 20 nov. 2016.

FOSTER, T.; BROZOVIĆ, N.; BUTLER, A.P.; NEALE, C.M.U.; RAES, D. et al. AquaCrop-OS: An open source version of FAO's crop water productivity model. Agricultural Water Management, v. 181, p. 18-22, 2017.

HE, D.; WANG, E.; WANG, J.; ROBERTSON, M.J. Data requirement for effective calibration of process-based crop models. Agricultural and Forest Meteorology, v. 234235, p. 136-148, 2017.

HENG, L.K.; HSIAO, T.; EVETT, S.; HOWELL, T.; STEDUTO, P. Validating the FAO AquaCrop model for irrigated and water deficient field maize. Agronomy Journal, v. 101, n. 3, p. 488-498, 2009.

HSIAO, T.C.; HENG, L.; STEDUTO, P.; ROJAS-LARA, B.; RAES, D.; FERERES, E. AquaCrop - The FAO crop model to simulate yield response to water: III. Parameterization and testing for maize. Agronomy Journal, v. 101, n. 3, p. 448-459, 2009.

INSTITUTO BRASILEIRO DE GEOGRAFIA E ESTATÍSTICA (IBGE). Produção Agrícola - Lavoura Temporária. 2019. Available at: <http://cidades.ibge.gov.br/>. Access on: 15 apr. 2019.

JONES, J.W.; ANTLE, J.M.; BASSO, B.; BOOTE, K.J.; CONANT, R.T. et al. Brief history of agricultural systems modeling. Agricultural Systems, v. 155, p. 240-254, 2017.

LECERF, R.; CEGLAR, A.; LÓPEZ-LOZANO, R.; VAN DER VELDE, M.; BARUTH, B. Assessing the information in crop model and meteorological indicators to forecast crop yield over Europe. Agricultural Systems, v. 168, p. 191202, 2019.

NGETICH, K.F.; RAES, D.; SHISANYA, C.A.; MUGWE, J.; MUCHERU-MUNA, M. et al. Calibration and validation of AquaCrop model for maize in sub-humid and semiarid regions of central highlands of Kenya. In: Research Application Summary, Third RUFORUM Biennial Meeting, Entebbe, Uganda. set. 2012. p. 1525-1548. Available at: $<$ https://www.researchgate.net/publication/281200550>. Access on: 05 Jun. 2019. 
PICHENY, V.; CASADEBAIG, P.; TRÉPOS, R.; FAIVRE, R.; SILVA, D. et al. Using numerical plant models and phenotypic correlation space to design achievable ideotypes. Plant, Cell \& Environment, v. 40, n. 9, p. 1926-1939, 2017.

PIEKARSKI, K.R.; SOUZA, J.L.M.; TSUKAHARA, R.Y.; OLIVEIRA, C.T.; ROSA, S.L.K. Simulação da produtividade de milho utilizando o modelo Aquacrop. Convibra Congresses Conferences, 2017. Available at: <http:// www.convibra.com.br/upload/paper/2017/83/ 2017_83_13582.pdf>. Access on: 03 jun. 2019.

PIERRI, L.; PAULETTI, V.; SILVA, D.A.; SCHERAIBER, F.; SOUZA, J.L.M.; MUNARO, F.C. Sazonalidade e potencial energético da biomassa residual agrícola na região dos Campos Gerais do Paraná. Revista Ceres, Viçosa, v. 63, n. 2, p. 129-137, 2016.

RAES, D.; STEDUTO, P.; HSIAO, T.C.; FERERES, E. Chapter 1: FAO crop-water productivity model to simulate yield response to water. AquaCrop Version 6.0 - 6.1. FAO. Rome, Italy: Reference Manual. 2018a. 19p.

RAES, D.; STEDUTO, P.; HSIAO, T.C.; FERERES, E. Chapter 2: Users guide. AquaCrop Version 6.0 - 6.1. FAO. Rome, Italy: Reference Manual. 2018b. 302p.

RAES, D.; STEDUTO, P.; HSIAO, T.C.; FERERES, E. Chapter 3: Calculation Procedures. AquaCrop Version 6.0 - 6.1. FAO. Rome, Italy: Reference Manual. 2018c. 141p.

RAES, D.; STEDUTO, P.; HSIAO, T.C.; FERERES, E. Annexes. AquaCrop Version 6.0 - 6.1. FAO. Rome, Italy. 2018d. Available at: <http://www.fao.org/3/a-br244e.pdf>. Access on: 19 feb. 2018.

RAN, H.; KANG, S.; LI, F.; DU, T.; TONG, T. et al. Parameterization of the AquaCrop model for full and deficit irrigated maize for seed production in arid Northwest China. Agricultural Water Management, v. 203, p. 438$450,2018$.
SCHIMANDEIRO, A.; KANTELHARDT, J.; WEIRICH NETO, P.H. Characterization of major crop management in the buffer zone of Vila Velha State Park, state of Paraná, Brazil. Acta Scientiarum. Agrononomy, Maringá, v. 30, n. 2, p. 225-230, 2008.

SOUZA, J.L.M.; GERSTEMBERGER, M.E.; ARAUJO, M.A. Calibração de modelos agrometeorológicos para estimar a produtividade da cultura do trigo, considerando sistemas de manejo do solo, em Ponta Grossa-PR. Revista Brasileira de Meteorologia, v. 28, n. 4, p. 409-418, 2013.

SOUZA, J.L.M.; JERSZURKI, D.; GOMES, S. Precipitação e evapotranspiração de referência prováveis na região de Ponta Grossa-PR. Brazilian Journal of Irrigation and Drainage, Botucatu, v. 19, n. 2, p. 279-291, 2014.

SOUZA, J.L.M.; PIEKARSKI, K.R.; TSUKAHARA R.Y.; GURSKI B.C. Atributos físico-hídricos de solos no sistema de plantio direto, Região dos Campos Gerais. Convibra Congresses Conferences, 2017. Available at: <http://www. convibra.com.br/upload/paper/2017/83/2017_83_13563. pdf>. Access on: 14 Mai. 2019.

SOUZA, J.L.M. Fundamentos de matemática e estatística para formulação de modelos e análise de dados: aplicado às ciências agrárias. Curitiba: Plataforma Moretti/ DSEA/SCA/ UFPR. (Série Didática). 2018.

STEDUTO, P.; HSIAO, T.C.; FERERES, E.; RAES, D. Crop yield response to water. Irrigation and Drainage Paper $\mathrm{N}^{\circ}$ 66, Rome: FAO, 2012. 500p. Available at: <http://www. fao.org/3/i2800e/i2800e.pdf>. Access on: 13 Mar. 2019

YIN, X.; VAN DER LINDEN, C.G.; STRUIK, P. C. Bringing genetics and biochemistry to crop modelling, and vice versa. European Journal of Agronomy, v. 100, p. 132140. 2018 .

License information: This is an open-access article distributed under the terms of the Creative Commons Attribution License (type CC-BY), which permits unrestricted use, distribution and reproduction in any medium, provided the original article is properly cited. 